\title{
THE IMPORTANCE OF CHANGING PERSPECTIVES: NON-EU ECOLABEL-CERTIFIED ESTABLISHMENTS IN THE HOSPITALITY INDUSTRY
}

\author{
ENRICA VESCE, CHIARA GIACHINO, RICCARDO BELTRAMO, AND PIERGIORGIO RE
}

Department of Management, University of Torino, Torino, Italy

\begin{abstract}
This study investigates how non-Ecolabel-certified establishments in the EU view the role of certification in the hospitality industry. The authors identified the strengths and weaknesses of the EU Ecolabel through structured questionnaires sent to both Ecolabel-certified and noncertified establishments in Piedmont, Italy. The originality of the study lies in the fact that the analysis was carried out mainly on establishments that have chosen not to adopt the certification. Their point of view is the most useful for gaining an understanding of the phenomenon, identifying effective initiatives, and investigating customers' perceptions. The findings contribute to the literature by providing a new perspective on non-Ecolabel establishments. From a managerial perspective, the study provides interesting insights for institutions and policymakers regarding the management and potential impacts of ecolabeling in the tourism sector, as well as the important factors to be considered by establishments in their marketing strategies.
\end{abstract}

Key words: European ecolabel; Tourism; Hospitality; Consumer awareness

Introduction

Ecolabels are information-driven policies and programs designed to inform consumers of the environmental impact of a product or service (Darnall, Ji, \& Vázquez-Brust, 2016; De Boer, 2003). The environmental label has always had a twofold objective: first, to reduce the information asymmetry that causes a lack of information on the characteristics of ecoproducts (i.e., products that share functions and claim to be more environmentally friendly than others); second, to reduce barriers between European countries (Vesce \& Beltramo, 2000), since many countries have been developing national environmental labeling programs, which create trade barriers between them (Beltramo, Maritano, \& Vesce, 2002; Maritano, Beltramo, \& Vesce, 1997).

Among the sectors in which the EU Ecolabel has been introduced, tourism has the greatest potential due to its consistent growth. Moreover, the advent of the web has required a rethinking of the business models adopted by some of the players (Giacosa, 
Giachino, Stupino, \& Mazzoleni, 2016). In this scenario, ecolabeling was seen as a possible source of competitive advantage for industry players (Han, Hsu, \& Lee, 2009).

The first Ecolabel criteria for tourism accommodation began to appear in 2003 (Council of the European Union, 2003, 2009a, 2009b, 2017), and the debate surrounding them soon began to intensify. Though ecolabeling had existed in the tourism sector for more than a decade (Font \& Buckley, 2001), certification remained poorly diffused.

The literature on EU ecolabeling has had mixed results. Ecofriendly initiatives have been found to be appreciated by customers (Chamorro \& Bañegil, 2006; Han et al., 2009; Vantomme, Geuens, De Houwer, \& De Pelsmacker, 2004), but ecolabeling appears to have little influence on customer decision making (Reiser \& Simmons, 2005). Moreover, establishments have no incentive to adopt EU certification due to its long and costly process (Geerts, 2014).

Some studies have sought an in-depth understanding of the phenomenon, but most have been focused on establishments that have already obtained EU certification (Lupu, Tanase, \& Tontoroiu, 2013) rather than on those who have decided to not adopt it.

To address this gap, this study investigates the main reasons why lead managers have decided not to adopt EU certification. The authors sent a questionnaire to both EU-certified and noncertified establishments to gather information from multiple perspectives. However, the focus is on noncertified establishments in the hospitality industry.

The rest of this article is organized as follows. First, the role of ecolabeling for products and services is explained. Second, the development of ecolabeling in the tourism sector and customers' perceptions and awareness are discussed. Third, the study's methodology and data analysis for noncertified establishments are presented. Finally, the authors outline the contributions and implications of the study and point to directions for future research.

\section{Literature Review}

\section{Role of Ecolabeling}

Ecolabeling (Council of the European Union, 1992) was intended as a voluntary tool of environmental regulation in the EU, marking a switch from a punitive logic, strictly based on a "command and control" philosophy, to a reward-based one.

Ecolabeling responded to an increasingly urgent consumer demand for sustainable products (Eurobarometer, 2014). It also represented a guarantee of environmental sensitivity, giving a competitive advantage to firms producing products with this label. Environmental protection bodies hoped that ecolabeling's incentive mechanisms would be more successful than earlier mandatory systems (Vesce \& Beltramo, 2000).

Ecolabeling regulations have been revised twice since being introduced (Council of European Union, 1992, 2010). Despite ecolabeling's wide diffusion among products and services, a general lack of understanding of its role persists.

Ecolabeling is based on life cycle analysis (LCA) (Baldo, Rollino, Stimmeder, \& Fieschi, 2002; Klöpffer, 2015), whereby only products and services that satisfy all relevant ecological criteria in every phase of the production process can be certified. The LCA method is a tool used to calculate the environmental impacts associated with a product or service. It is governed by International Standard Organization (ISO) standards (ISO, 1997, 1998, $2000,2017)$ and takes into consideration the whole life of the product or service, from cradle to grave. The LCA is at the base of the ecolabel process, and the literature generally assesses it positively (Baldo et al., 2002; Lewandowska et al., 2013).

Ecolabeling rewards excellence because it is assigned to the best environmental products within the same functional category and with the same functional purpose. Ecolabeling is also a selective process, as certification is awarded to only a small percentage of products on the market.

However, several aspects of the process have had negative influences on the diffusion of the EU label, due largely to its "multicriteria" logic, which is more complete but also more complex than other environmental marking schemes. For example, the bureaucratic difficulties in obtaining certification and consumers' lack of knowledge of (Lupu et al., 2013) and interest in (Eurobarometer, 2014; Leire $\&$ Thidell, 2005) the process have led to a weak diffusion of the label.

Twenty-five years after the birth of the EU Ecolabel, it is worthwhile examining its application among various sectors, especially given the 
considerable efforts that have been made at the EU level to promote and support certification (D’Alessandro \& Masoni, 2015).

\section{Ecolabeling in the Tourism Sector}

A community's approach to sustainability is a fundamental factor in tourism development. This factor can be measured through several indicators (Choi \& Turk, 2011).

Ecolabels are one of the "most promising voluntary initiatives" for improving the sustainability of tourist destinations (Rodríguez, López, \& Caballero, 2017) and can be seen as both a marketing and environmental management tool that can increase competitive advantage (Fairweather, Maslin, \& Simmons, 2005; Font \& Buckley, 2001). Despite this fact, the EU Ecolabel is controversial in the tourism sector. Few studies have examined the benefits it brings to the industry (Ban, Iacobas, \& Nedelea, 2015; Millar \& Baloglu, 2011).

The first criteria for accommodation in the EU tourism sector appeared in 2003 (Council of European Union, 2003), and debates about them began immediately. Tourism accommodation is dynamic, as supply changes depending on customers' demand. The ability to stay ahead of the competition is linked to the speed with which new services can be offered, which depends on a combination of products, materials, energy, and know-how. These elements are all linked to the LCA. In the tourism sector, however, it is very difficult to find a perfect benchmark for LCA, and few case studies have measured the impact of environmental initiatives in the hospitality sector (De Camillis, Raggi, \& Petti, 2010; Iraldo \& Nucci, 2016).

The introduction of ecolabeling criteria for tourism accommodation generated competition between the EU Ecolabel and environmental management systems like EMAS (Masone \& Ruzzolini, 2017; Vesce \& Beltramo, 2000), the official European tool by which economic organizations pursue the continual improvement of their environmental performance. It also generated confusion among some economic operators. Overall, ecolabeling has seen changing fortunes.

Interest in ecolabeling for tourism was motivated by growth in this sector and the subsequent direct and indirect environmental burdens (Blanca,
Lozano Oyola, \& Gonzales, 2015; Dziuba, 2016). The number of Ecolabel licenses granted in the Italian tourism sector increased from 2 to 200 between 2004 and 2017.

From 2007 to 2009, ecolabeling in the tourism sector increased. In 2010, however, certification decreased due to the introduction of new criteria. In 2017, the number of licenses reached its peak. Although the trend was positive, the absolute number of certifications was quite low.

It is not easy to evaluate the usefulness convenience of a tool that entails environmental costs and benefits. Any analysis of the advantages and disadvantages of Ecolabel implementation (Karlsson \& Dolnicar, 2016) or of the purchase of labeled products should include a consideration of the savings achieved in terms of avoided pollution and unused resources, which are difficult to estimate (AEAT, 2004).

In implementing ecolabeling, producers must be able to afford principal costs for fees and maintenance. It can thus be assumed that service providers face other costs (e.g., structural modifications), and it is unclear how higher costs bring advantages (e.g., energy savings; Iraldo \& Barberio, 2017).

To obtain ecolabel certification, hotel managers have to fulfill 84 mandatory and optional criteria for energy saving, waste reduction, and the use of low environmental impact substances (Vidal-Abarca et al., 2016).

All these criteria include requirements relating to assessments and audits. The division between mandatory and optional requirements allows flexibility, which is necessary because the tourist accommodation sector offers various services that have different environmental impacts and are located in areas with different environmental restrictions.

\section{Point of View of Hospitality Sector Managers and Consumer Perceptions of Certification}

In general, ecolabels provide information on products and services and can be used as a powerful marketing tool (Kavaliauske, Vaskiv, \& Seimiene, 2013), as they communicate how companies operate at a quality and environmental level (Grunert, 1993). However, the research suggests that it is difficult to evaluate customers' overall reaction to ecolabels in the tourism sector, as well as in other sectors 
(Campisi, Marinatto, \& Bogoni, 2014). However, understanding the decision-making processes, attitudes, and behaviors of tourists is crucial (Atadil, Sirakaya-Turk, \& Decrip, 2017; Atadil, SirakayaTurk, Meng, \& Decrop, 2018; Bigovic, 2014).

Studies on consumers show that sustainability can influence peoples' choices in different ways (Bonadonna, Giachino, \& Truant, 2017; Chen \& Peng, 2016; Fatima, Khan, \& Halabi, 2017; Sirakaya-Turk, Baloglu, \& Mercado, 2014; Yoon $\&$ Chen, 2017) and that, although people are concerned about the environment and its preservation, they tend to have inconsistent views about preserving the natural environment at the moment of purchase, and particular feelings can influence their choice particularly strongly (Vantomme et al., 2004; Yoon \& Chen, 2017).

In their study on Lithuanian consumers, Kavaliauske et al. (2013) found that buying choices were not driven or influenced by the presence of ecolabels (apart from a few consumer niches; Karlsson \& Dolnicar, 2016), likely because they knew little about them. Aarset et al. (2004) found that consumers' trust in ecological schemes was low, although their investigation of customers' reactions to green behaviors revealed a positive reaction toward companies that were adopting virtuous behaviors (Han et al., 2009).

Certification in the hospitality industry is important for three main reasons: it helps sets new environmental standards, it helps create new marketing tools, and third-party certification can make the process more objective (Proebstl \& Mueller, 2013).

Environmental changes are sometimes difficult to communicate to customers, and ecolabeling does not seem to have a consistent impact on tourist demand (Karlsson \& Dolnicar, 2016). Managers usually use certification as an additional valueadded service the same way they use brands, prices, and other amenities (Brown \& Ragsdale, 2002), being aware that certification has little influence on tourists' decision-making processes (Karlsson \& Dolnicar, 2016; Reiser \& Simmons, 2005). A recent study on Italian hospitality establishments found that managers used certifications to improve their image among guests (Duglio, Ivanov, Magliano, \& Ivanova, 2017).

Research conducted on the hospitality industry and ecolabeling by the Provincia Autonoma di
Trento in 2015 provided interesting insights into the topic. In line with previous studies, it found that most clients were not interested in certification but they recognized the importance of having a sustainable attitude towards the environment (Heiskanen \& Timonen, 1996; Leire \& Thidell, 2005). Of those interviewed, $45 \%$ thought that the EU Ecolabel was trustworthy, but they were unsure what criteria were required to obtain it (Provincia Autonoma di Trento, 2015). These results illustrate the confusion among consumers and clients but also confirm that interest in the environment and its protection is growing (Niva \& Timonen, 2001; Thøgersen, Haugaard, \& Olesen, 2010).

The same study investigated the views of tourist establishment managers, finding that satisfaction with certification was not particularly high. It was generally recognized that certification brought economic benefits, such as the potential for financial aid and better resource use, as well as environmental benefits such as $\mathrm{CO}_{2}$ emissions reduction and lower water and energy use. However, managers said it also carried costs, such as for adopting new technologies and purchasing Ecolabel products (Provincia Autonoma di Trento, 2015). Ultimately, the managers claimed that tourists, except for some family group and foreign tourists, were not interested in ecocertification.

\section{Methods}

To understand the potential of ecolabeling in the tourism industry, it is essential to identify why managers are not adopting EU certification. Thus, this study seeks to identify the main reasons for hospitality managers' nonadoption of EU certification. To this end, a questionnaire was sent to both EU-certified and noncertified establishments, though the focus is on establishments that chose not to adopt ecolabeling.

Focusing on the Piedmont area, the authors identified establishments with and without EU Ecolabel certification. The Piedmont area is a suitable setting for this initial investigation because it, together with the Puglia region, has the higher number of EU-certified establishments. This means that establishments in the region have experience with the possibilities that EU Ecolabel certification brings. Of course, each region has specific characteristics 
that can influence the decision of whether to adopt EU certification.

The research process comprised three main activities. The authors first reviewed the literature on ecolabeling and relevant studies conducted by research institutes designed to understand how certification affects customers' choices. Then two questionnaires were created to evaluate the establishments' perceptions of ecolabeling and assess the attitudes of hospitality management toward certification and its utility. Though the focus was on noncertified establishments, the authors also collected data from 15 EU-certified establishments in Piedmont to gain a complete overview of the topic. This double perspective allowed the authors to identify a wider range of motivations that could lead managers to adopt ecolabeling (or not). Two questionnaires were created based on the key evidence drawn from both the literature review and other research. One questionnaire was sent to establishments with ecolabeling certification, and the other was sent to establishments without. The questionnaires were sent via Google Forms. They were anonymous, but the respondents could leave their contact details at the end of the questionnaire. The questionnaires were sent to the main email address found on the websites of the establishments, addressed to each establishments' manager/responsible employee. Third and finally, the authors analyzed the results to identify the major issues that emerged.

\section{Data Collection}

The study examined all 15 establishments in the Piedmont area with EU Ecolabel certification. The authors selected 690 noncertified establishments located in the same area as those that were ecolabel certified. Focusing on a single area minimizes the influence of external factors (i.e., economy, presence of tourist attractions). Nine of the $15 \mathrm{EU}$ ecolabel-certified establishments responded, for a response rate of $60 \%$. The authors contacted the 690 non-EU Ecolabel-certified establishments and received 69 responses, for a response rate of $10 \%$.

The questionnaire for the EU Ecolabel-certified establishments was divided into three main sections. The first covered general data [i.e., manager/ responsible employee of the establishment, accommodation type, number of clients/year, size $\left(\mathrm{m}^{2}\right)$, year of certification]. The second section covered the motivation for adopting ecolabeling (i.e., how they learned of EU Ecolabel certification, why they decided to adopt it, their satisfaction, clients' comments on the certification, its influence on the number of clients/year). The third section covered the economic impact of certification (i.e., costs of adopting ecolabeling, the economic benefits, the environmental impacts). For the questionnaire given to the noncertified establishments, the first section was the same as that in the questionnaire given to certified establishments. The second covered the respondents' level of awareness of EU Ecolabel certification (e.g., if they were aware of it, how they learned about it). The third part covered perceived opportunities and barriers linked to certification.

Findings and Results

\section{EU Ecolabel-Certified Establishments}

The responses indicated that most of the establishments had obtained certification relatively recently (in 2017, the end of 2016, in 2014, or in 2011), with the exception of one that received certification in 2005 (see Table 1).

The evidence highlighted the role of institutions in communicating ecolabel certification to establishments. Almost all the establishments interviewed were aware of ecolabel certification thanks to the initiatives of specific institutions (e.g., Arpa). The evidence also highlighted the importance of implementing sustainable activities. Many establishments decided to adopt certification because of their

Table 1

General Data: EU Ecolabel-Certified Establishments

\begin{tabular}{lccc}
\hline Structure & $\mathrm{Mq}$ & Clients/Year & Year of Certification \\
\hline 1 & $400-600$ & $<2,000$ & 2011 \\
2 & $<100$ & $<2,000$ & 2005 \\
3 & $>100$ & $<2,000$ & 2017 \\
4 & $600-800$ & $4,000-10,000$ & 2014 \\
5 & $100-200$ & $<2,000$ & 2016 \\
6 & $800-1,000$ & $<2,000$ & 2014 \\
7 & $>1,000$ & $<2,000$ & 2017 \\
8 & $400-600$ & $<2,000$ & 2014 \\
9 & $>1,000$ & $10,000-20,000$ & 2016 \\
10 & $<1,000$ & $10,000-20,000$ & 2016 \\
\hline
\end{tabular}

Source: Authors' elaboration. 
interest in sustaining the region through the implementation of ecofriendly initiatives. Only one of the respondents said that the major reason for adopting ecolabeling was to obtain economic benefits.

The respondents' level of satisfaction was generally high, of an average of about 4 (on a 4-point Likert scale), and some of the respondents were very satisfied with their choice (scoring 5 out 5). Only one respondent was disappointed (2 out of 5). The other eight received the benefits they had anticipated (indicating 3, 4, or 5 out of 5). The eight respondents who responded positively eventually chose certification.

The respondents who indicated that they were not interested in repeating the certification process also indicated that customers were unaware of the initiative and that it had not had a positive impact on the establishment. According to other respondents, most of the customers who were interested in certification were foreign tourists, young people, and family groups. However, most of the establishments stated that customers were not influenced by ecolabeling during the booking process. In fact, the respondents claimed that there was no positive correlation between the adoption of ecolabeling and an increase in reservations. It seems that people do not pay attention to the presence of certification. Only four respondents stated that there was significant awareness of EU Ecolabel certification among customers.

In terms of economic benefits, only four respondents confirmed a positive return, citing a reduction of between $10 \%$ and $30 \%$ in the costs of water, energy, and gas. However, high costs were also incurred when implementing the requirements necessary to obtain certification.

\section{Non-EU Ecolabel-Certified Establishments}

The authors collected information from 69 of the 690 noncertified establishments identified in the same municipalities where there was at least one certified establishment. Regarding the role of communication, $46 \%$ of the respondents indicated that they were aware of ecolabel certification due to communication from specific institutions (e.g., Arpa) or via word of mouth. Approximately half of the establishments interviewed were aware of ecolabel certification, indicating that the experience of other establishments has contributed to making certification more popular. The establishments decided to not adopt certification for various reasons. Approximately $55 \%$ of respondents indicated that they had already implemented ecofriendly initiatives, and approximately $9 \%$ claimed that it was not necessary to have certification to preserve the environment. Moreover, approximately $20 \%$ indicated that the bureaucracy and costs involved were too great or that multiple negative elements had influenced their decision. All of the establishments agreed that it was possible to obtain environmental advantages without ecolabel certification.

Most of the non-EU-certified establishments indicated that the need to implement sustainable initiatives and preserve the environment was the most important factor in introducing ecofriendly initiatives. The importance of the region is paramount, and establishments should try to consider both the positive and negative effects of their actions on the environment, even if they lack ecolabel certification.

Another important piece of evidence that emerged concerns the customers. Overall, $82 \%$ of the establishments seemed to be certain that customers are most interested in the establishments' services and prices and that only few are interested in ecolabel certification. Currently, ecolabel certification does not seem to be a reason to make a booking as far as customers are concerned.

\section{Discussion and Conclusions}

Ecolabeling represents an important step toward the safeguarding of the environment (Darnall et al., 2016; De Boer, 2003). However, it has still not spread throughout the hospitality industry. Industry criteria started to appear 15 years ago (Council of European Union, 2003, 2009a, 2009b, 2017), but their influence on tourists' choices remains weak (Reiser \& Simmons, 2005). Though the study is not focused on establishments with certification, it is difficult to clearly identify the competitive advantages certification has produced (Geerts, 2014; Lupu et al., 2013). For this reason, it is necessary to understand why establishments choose to adopt it (or not). The authors sought to shed light on the perspectives of both EU Ecolabel-certified and noncertified establishments, with particular attention paid to the latter, which are underinvestigated in the literature. 
The results obtained in this preliminary study on Piedmont establishments identified three main points of interest: the importance of ecofriendly initiatives, the establishments' awareness of ecolabeling, and institutions' level of communication and dissemination of ecolabeling initiatives.

Regarding the third point, the evidence revealed the important role played by institutions in communicating the existence of certification. All the establishments with ecolabel certification and half of those without it were aware of the process due to initiatives promoted by local and regional institutions. The experiences of other establishments also emerged as an important factor; word of mouth seems to be important in influencing establishments' choices, and this is why it is important to constantly monitor establishments' perspectives.

The second point, regarding establishments' and customers' awareness of ecolabeling, is connected to the first. The results show that most respondents are aware of ecolabeling. However, the number of establishments that have adopted it is significantly lower than the number of those who decided not to. Being aware of the existence of ecolabel certification is important, but industry players also need to communicate the benefits of having it; otherwise, few establishments will decide to invest in it (Ban et al., 2015; De Camillis et al., 2010; Iraldo \& Nucci, 2016; Millar \& Baloglu, 2011). The function of ecolabels is to provide quality and environmental information (Grunert, 1993).

To convince establishments to adopt certification, it is necessary to identify not only the benefits linked to the environment but also those linked to business (Iraldo \& Barberio, 2017). The economic aspects are important for those operating in the tourism sector, as well as in other sectors; however, the benefits have not been communicated clearly (AEAT, 2004; Iraldo \& Barberio, 2017). From this perspective, customers' awareness can influence the entire process of certification. However, customers seem unaware of certification, and certification does not operate as a relevant decision-making factor for them (Karlsson \& Dolnicar, 2016). It is difficult to identify a common customer reaction to EU Ecolabels (Campisi et al., 2014).

Finally, regarding the third point, the importance of ecofriendly initiatives, customers seem to be sensitive to these initiatives (Han et al., 2009) but not necessarily to certification (Heiskanen \& Timonen, 1996; Karlsson \& Dolnicar, 2016; Leire \& Thidell, 2005). Establishments indicated an intention to implement and communicate ecofriendly initiatives even if they did not have certification, and customers seemed to appreciate this. It is well-known that most people are concerned about the environment (Vantomme et al., 2004), and the study's evidence seems to confirm this. Thus, the adoption of certification seems to have no influence on customers' choices, but it is enough for establishments to show that they are paying attention to the environment. To reinforce this point, the evidence shows that some establishments adopted ecolabeling due to their interest in its environmental impact. They are satisfied with their choice, but there are no data on whether certification affected the establishments' economic return.

The findings of previous ecolabeling studies and of specific research on Piedmont feature differences and similarities (Provincia Autonoma di Trento, 2015). Some of the literature has found that awareness of ecolabeling is generally low, while more recent research has identified a high level of awareness among establishments (Provincia Autonoma di Trento, 2015). The attitudes of both establishments and tourists are changing, and the important role of environmental awareness has been recognized by all the actors involved (Alessi \& Masone, 2013). Another important factor is the perceived client awareness of certification. Management reports low client awareness and a low influence of certification on clients' decision making (Karlsson \& Dolnicar, 2016; Kavaliauske et al., 2013).

More attention must be paid to client profiles. Identifying the clients who are most interested in certification is important because it would allow establishments to customize their marketing strategies.

Finally, the importance of ecolabeling due to the impact it can have on the environment is generally recognized, but its economic impacts provide establishments with additional incentive to pursue it.

\section{Contributions and Future Research}

This research on establishments in Piedmont is the first investigation into how establishments with and without EU Ecolabel certification perceive the EU Ecolabel as well as into customers' point 
of view on the topic. This study contributes to the literature by providing insight into the perspective of non-EU-certified establishments, which have so far been underinvestigated. This study can help both researchers and experts understand why the diffusion of ecolabeling is relatively low among hospitality establishments. Most of the studies on ecolabeling in the tourism sector have analyzed establishments that are certified.

From a managerial point of view, these findings can help industry players to understand certification's mechanism. Institutions and organizations have communicated effectively regarding EU Ecolabel certification to the hospitality industry. This study shows the need to understand the real drivers that can influence establishments' choices and to communicate them in order to convince managers to adopt EU certification. Moreover, the low awareness of EU certification among tourists and customers indicates that institutions must communicate regarding certification to customers as well, and find new ways to assist customers in choosing Ecolabel-certified establishments.

Establishment managers consider it important to preserve the environment, and most have implemented ecofriendly initiatives, but they have to communicate about those initiatives with customers. This is critical for increasing awareness among tourists.

Considering that the aim of the EU Ecolabel is to help the environment through ecofriendly initiatives, it is necessary to reflect on whether Ecolabel certification is necessary, or if it would be more effective to help establishments be more ecofriendly. If having certification means incurring costs while failing to be recognized by customers, institutions should probably rethink the system.

This study opens the door to further research. A more in-depth analysis of the costs and benefits of ecolabeling could be performed. Further study could also identify the main factors affecting EU certification in specific regions. More in-depth analyses of tourists could help both managers and institutions understand the relationship between certification and booking. The profiles of tourists in various categories could also be analyzed to evaluate the importance tourists ascribe to certification or noncertification. A more detailed profiling of customers and of the drivers that can influence their booking choices could be useful to managers in the hospitality industry.

\section{Acknowledgments}

A special thanks to Chiara Gaidano for her commitment.

\section{References}

Aarset, B., Beckmann, S., Bigne, E., Beveridge, M., Bjorndal, T., Bunting, J., . . \& \& Reisch, L. (2004). The European consumers' understanding and perceptions of the "organic" food regime: The case of aquaculture. British Food Journal, 106(2), 93-105.

AEAT. (2004). The direct and indirect benefits of the European Ecolabel-Final report. Retrieved from http:// ec.europa.eu/environment/ecolabel/about_ecolabel/ reports/benefitsfinalreport_1104.pdf

Alessi, R., \& Masone, M. (2013). Indagine sulle strutture ricettive a marchio Ecolabel UE. Retrieved from http://www.isprambiente.gov.it/it/certificazioni/news/ pubblicato-indagine-sulle-strutture-ricettive-a-marchioecolabel-ue

Atadil, H. A., Sirakaya-Turk, E., \& Decrop, A. (2017). An assessment of decision-making styles: An abstract. In Marketing at the confluence between entertainment and analytics (pp. 817-818). Cham, Switzerland: Springer.

Atadil, H. A., Sirakaya-Turk, E., Meng, F., \& Decrop, A. (2018). Exploring travelers' decision-making styles. International Journal of Contemporary Hospitality Management, 30(1), 618-636.

Baldo, G. L., Rollino, S., Stimmeder, G., \& Fieschi, M. (2002). The use of LCA to develop eco-label criteria for hard floor coverings on behalf of the European flower. The International Journal of Life Cycle Assessment, 7(5), 269-275.

Ban, O. I., Iacobas, P., \& Nedelea, A. M. (2015). Marketing research regarding tourism business readness for Ecolabel achievement (Case Study: Natura 2000 Crisul Repete Gorge-Padurea Craiului Pass Site, Romania). Journal of Tourism - Studies and Research in Tourism, 20, 16-26.

Beltramo, R., Maritano, E., \& Vesce, E. (2002). Sistemi di gestione e marchi ambientali per imprese ecoefficienti-una guida interattiva per valutare e migliorare le prestazioni della propria impresa (Vol. 1). Torino, Italy: Celid.

Bigovic, M. (2014). The simultaneous effect of emotional and rational response on tourists' intended behavior. Tourism Analysis, 19(4), 517-523.

Blanca, F. J., Lozano Oyola, M., \& Gonzales, M. (2015). A European sustainable tourism labels proposal using a composite indicator. Environmental Impact Assessment Review, 54, 39-54.

Bonadonna, A., Giachino, C., \& Truant, E. (2017). Sustainability and mountain tourism: The millennial's perspective. Sustainability, 9(7), 1219 
Brown, J. R., \& Ragsdale, C. T. (2002). The competitive market efficiency of hotel brands: An application of data envelopment analysis. Journal of Hospitality \& Tourism Research, 26(4), 332-360.

Campisi, B., Marinatto, F., \& Bogoni, P. (2014). The European Ecolabel in the tourist sector: An analysis of the Italian experience of mountain huts. In Pathways to environmental sustainability (pp. 257-266). Cham, Switzerland: Springer.

Chamorro, A., \& Bañegil, T. M. (2006). Green marketing philosophy: A study of Spanish firms with ecolabels. Corporate Social Responsibility and Environmental Management, 13(1), 11-24.

Chen, A., \& Peng, N. (2016). Examining Chinese tourists' nature-based tourism participation behavior: Incorporating environmental concern into a constraint-negotiation model. Tourism Analysis, 21(2-3), 189-202.

Choi, H. C., \& Turk, E. S. (2011). Sustainability indicators for managing community tourism. In Quality-of-life community indicators for parks, recreation and tourism management (pp. 115-140). Dordrecht, Netherlands: Springer.

Council of European Union. (1992). Regulation (EEC) No 880/92 23 March 1992 on a Community eco-label award scheme. Retrieved from https://publications.europa.eu/ en/publication-detail/-/publication/20efa09f-6400-4b25ac1b-12d16a564e9c

Council of European Union. (2000). Regulation (EC) no. 1980/2000 of the European Parliament and of the council of 17 July 2000 on a revised community Eco-label award scheme. Retrieved from http://ec.europa.eu/environment/ archives/ecolabel/pdf/regulation/001980_en.pdf

Council of European Union. (2003). Commission Decision of 14 April 2003 establishing the ecological criteria for the award of the Community eco-label to tourist accommodation service (Text with EEA relevance) (notified under document number C(235). Retrieved from https://publications.europa.eu/en/publication-detail/-/ publication/b3461abf-ca30-4292-9a2b-1d8c039da11b

Council of European Union. (2009a). Commission Decision of 9 July 2009 establishing the ecological criteria for the award of the Community eco-label for tourist accommodation service (Text with EEA relevance). Retrieved from https://publications.europa.eu/en/publication-detail/-/ publication/fb3b45ff-1cf3-46c4-9be4-357d189fb746/ language-en

Council of European Union. (2009b). Commission Decision of 9 July 2009 establishing the ecological criteria for the award of the Community eco-label for campsite service (Text with EEA relevance). Retrieved from https://publications.europa.eu/en/publication-detail/-/ publication/38a51a60-2afe-4063-838e-f2400f80093e

Council of European Union. (2010). Regulation (EC) no. 66/2010 of the European Parliament and of the council of 25 November 2009 on the EU Ecolabel. Retrieved from https://eur-lex.europa.eu/LexUriServ/LexUriServ. do?uri=OJ:L:2010:027:0001:0019:en:PDF

Council of European Union. (2017). Commission Decision (EU) 2017/175 of 25 January 2017 on establishing EU
Ecolabel criteria for tourist accommodation (Text with EEA relevance). Retrieved from https://publications. europa.eu/en/publication-detail/-/publication/2b1a912ae8d8-11e6-ad7c-01aa75ed71a1

D’Alessandro, B., \& Masoni, M. (2015). benefici ed incentivi a livello locale per l'adesione ad EMAS ed ECOLABEL. Retrieved from http://www.isprambiente.gov.it/it/ certificazioni/files/articoli/benefici-e-incentivi-a-livellolocale-per-12019adesione-ad-emas-ed-ecolabel

Darnall, N., Ji, H., \& Vázquez-Brust, D. A. (2016). Thirdparty certification, sponsorship, and consumers' ecolabel use. Journal of Business Ethics, 1-17.

De Boer, J. (2003). Sustainability labelling schemes: The logic of their claims and their functions for stakeholders. Business Strategy and the Environment, 12(4), 254-264.

De Camillis, C., Raggi, A., \& Petti, L. (2010). Tourism LCA: State-of-the-art and perspectives. The International Journal of Life Cycle Assessment, 15(2), 148-155.

Duglio, S., Ivanov, S. H., Magliano, F., \& Ivanova, M. G. (2017). Motivation, costs and benefits of the adoption of the European Ecolabel in the tourism sector: An exploratory study of Italian accommodation establishments. Izvestiya Journal of Varna University of Economics, 61(1), 83-95.

Dziuba, R. (2016). Sustainable development of tourism-EU Ecolabel standards illustrated using the example of Poland. Comparative Economic Research, 19(2), 111-128.

Eurobarometer. (2014). Attitudes of European citizens towards the environment (Special Eurobarometer 416). Retrieved from http://ec.europa.eu/public_opinion/ archives/ebs/ebs_416_en.pdf

Fairweather, J. R., Maslin, C., \& Simmons, D. G. (2005). Environmental values and response to ecolabels among international visitors to New Zealand. Journal of Sustainable Tourism, 13(1), 82-98.

Fatima, J. K., Khan, H. Z., \& Halabi, A. K. (2017). Ecotourism participation intention in Australia: Mediating influence of social interactions. Tourism Analysis, 22(1), $85-91$.

Font, X., \& Buckley, R. (Eds.). (2001). Tourism ecolabelling: Certification and promotion of sustainable management. New York, NY: CABI.

Geerts, W. (2014). Environmental certification schemes: Hotel managers' views and perceptions. International Journal of Hospitality Management, 39, 87-96.

Giacosa, E., Giachino, C., Stupino, M., \& Mazzoleni, A. (2016). A tour operator with a global, innovative spirit: The case of AlpitourWorld. Tourism Analysis, 21(2-3), 267-277.

Grunert, S. C. (1993). Everybody seems concerned about the environment: But is this concern reflected in (Danish) consumers' food choice? ACR European Advances, 1, 428-433.

Han, H., Hsu, L. T. J., \& Lee, J. S. (2009). Empirical investigation of the roles of attitudes toward green behaviors, overall image, gender, and age in hotel customers' ecofriendly decision-making process. International Journal of Hospitality Management, 28(4), 519-528. 
Heiskanen, E., \& Timonen, P. (1996). Environmental information and consumer decisions: Final report: Consumers' needs for environmental information. National Consumer Research Centre. Publication, 9.

International Standard Organization. (1997). ISO 14040: Environmental management-Life cycle assessmentPrinciples and framework. Geneva: Author.

International Standard Organization. (1998). ISO 14041: Environmental management_Life cycle assessmentGoal and scope definition and inventory analysis. Geneva: Author.

International Standard Organization. (2000). ISO 14042: Environmental management - Life cycle assessmentLife cycle impact assessment. Geneva: Author.

International Standard Organization. (2017). ISO 14043: Environmental management - Life cycle assessmentLife cycle interpretation. Geneva: Author.

Iraldo, F., \& Barberio, M. (2017). Drivers, barriers and benefits of the EU Ecolabel in European companies' perception. Sustainability, 9(5), 751.

Iraldo F., \& Nucci B., (2016). Proactive environmental management in hotels: What difference does it make? Economics and Policy of Energy and the Environment, 2016(2), 81-106. doi: 10.3280/EFE2016-002005.

Karlsson, L., \& Dolnicar, S. (2016). Does eco certification sell tourism services? Evidence from a quasiexperimental observation study in Iceland. Journal of Sustainable Tourism, 24(5), 694-714.

Kavaliauske, M., Vaskiv, U., \& Seimiene, E. (2013). Consumers' perception of Lithuanian eco-label. Economics and Management, 18(4), 802-815.

Klöpffer, W. (2015). Life cycle assessment-From the beginning to the current state (1997). Environmental Science \& Pollution Research, 4, 223-228.

Leire, C., \& Thidell, A. (2005). Product-related environmental information to guide consumer purchases-A review and analysis of research on perceptions, understanding and use among Nordic consumers. Journal of Cleaner Production, 13(10-11), 1061-1070.

Lewandowska A., Kurczewski P., Kulczycka J., Joachimiak K., Matuszak-Flejszman A., Baumann H., \& Ciroth A., (2013). LCA as an element in environmental management systems - Comparison of conditions in selected organisations in Poland, Sweden and Germany. International Journal of Life Cycle Assessment, 18, 472-480.

Lupu, N., Tanase, M. O., \& Tontoroiu, R. A. (2013). A straightforward $\mathrm{x}$-ray on applying the Ecolabel to the hotel business area. Amfiteatru Economic Journal, 15(Special No. 7), 634-644.

Maritano, E., Beltramo, R., \& Vesce E. (1997). Environment \& company. Milano, Italy: Angelo Guerini e associati Spa.

Masone, M., \& Ruzzolini G. (2017). EMAS ed Ecolabel come strumenti per la valorizzazione di un territorio a vocazione turistica, ispra ambiente. Retrieved from http://www.isprambiente.gov.it/it/certificazioni/files/ emas/2017/emas-ed-ecolabel-come-strumenti-per-lavalorizzazione-di-un-territorio-a-vocazione-turistica

Millar, M., \& Baloglu, S. (2011). Hotel guests' preferences for green guest room attributes. Cornell Hospitality Quarterly, 52, 302-311.

Niva, M., \& Timonen, P. (2001). The role of consumers in product-oriented environmental policy: Can the consumer be the driving force for environmental improvements? International Journal of Consumer Studies, 25(4), 331-338.

Proebstl, U., \& Mueller, F. (2013). Hotel certification and its relevance for sustainable development: Examples from the European Alps. Tourism as a Challenge, 5, 105.

Provincia autonoma di Trento. (2015). Valutazione degli impatti ambientali, economici e culturali derivanti dall'applicazione in Trentino del marchio di qualità ambientale Ecolabel europeo per il turismo. Retrieved from http://www.appa.provincia.tn.it/sviluppo sostenibile/ valutazione_marchi_qualita_ambientale/valutazione_ ecolabel/

Reiser, A., \& Simmons, D. G. (2005). A quasi-experimental method for testing the effectiveness of ecolabel promotion. Journal of Sustainable Tourism, 13(6), 590-616.

Rodríguez, R. A., López, A. G., \& Caballero, J. L. J. (2017). Has implementing an ecolabel increased sustainable tourism in Barcelona? Cuadernos de turismo, 93-134.

Sirakaya-Turk, E., Baloglu, S., \& Mercado, H. U. (2014). The efficacy of sustainability values in predicting travelers' choices for sustainable hospitality businesses. Cornell Hospitality Quarterly, 55(1), 115-126.

Thøgersen, J., Haugaard, P., \& Olesen, A. (2010). Consumer responses to ecolabels. European Journal of Marketing, 44(11/12), 1787-1810.

Vantomme, D., Geuens, M., De Houwer, J., \& De Pelsmacker, P. (2004). Implicit attitudes toward green consumer behavior. Psychologica belgica, 45(4).

Vesce E., \& Beltramo R. (2000). Il nuovo Regolamento Ecolabel e l'applicazione del marchio ai servizi turistici, Europa e diritto. L'informazione dell'Unione Industriale, Unione Industriale di Torino, 2, pp. 24-29.

Vidal-Abarca, C., Rodríguez, R., Wolf, O., Bojczuk, K., Castella, T., \& Tewson, J. (2016). Revision of European Ecolabel criteria for tourist accommodation and camp site services. Final criteria proposal. Retrieved from http://ec.europa.eu/environment/ecolabel/documents/ ecolabel tourist accomodation service technical report.pdf

Yoon, D., \& Chen, R. J. (2017). A green shadow: The influence of hotel customers' environmental knowledge and concern on green marketing skepticism and behavioral intentions. Tourism Analysis, 22(3), 281-293. 